\title{
PENGARUH GOOD CORPORATE GOVERNANCE, REPUTASI UNDERWRITER DAN ROA TERHADAP UNDERPRICING TAHUN 2016-2019
}

\author{
Jazzlin Marvella Gunawan, Kazia Laturette \\ Fakultas Manajemen dan Bisnis, Universitas Ciputra Surabaya \\ e-mail: jazzlinmarvella17@gmail.com
}

\begin{abstract}
One of the phenomena that occur in Indonesia capital market is underpricing. The underpricing phenomenon occurs when IPO shares are priced lower in the primary market than the closing price on the secondary market. The high level of underpricing can be detrimental to the company because the additional capital obtained through the IPO is not optimal, while the beneficiaries are investors because they get the initial return. This study purpose was to examine the influence of the components of Good Corporate Governance which include the board of commissioners, the independent board of commissioners, the board of directors and ownership concentration, non-financial variables, namely underwriter reputation and financial variables, namely Return On Assets (ROA) on underpricing. Samples were taken using the purposive sampling method. The number of samples finally used was 123 companies from all company sectors that conducted IPOs on the Indonesia Stock Exchange in the 2016-2019 period and experienced underpricing. This study used secondary data obtained from the prospectus, annual report, e-bursa and IDX Factbook in 2016-2019. The results of the multiple linear regression test show that variables including the board of commissioners, independent board of commissioners, board of directors and ROA have a significant negative effect on underpricing which means the larger/higher these variables can minimize underpricing. While the concentration of ownership and underwriter's reputation did not influence underpricing.
\end{abstract}

Keywords: underpricing; underwriter reputation; good corporate governance; ROA; IPO

\begin{abstract}
ABSTRAK
Fenomena yang sering terjadi di pasar modal Indonesia salah satunya yaitu underpricing. Fenomena underpricing terjadi saat saham IPO penetapan harganya di pasar perdana lebih rendah dibandingkan harga penutupan di pasar sekunder. Tingkat underpricing yang tinggi dapat merugikan perusahaan karena tambahan modal yang didapatkan melalui IPO tidak maksimal, sedangkan pihak yang diuntungkan adalah investor karena mendapatkan initial return. Tujuan penelitian ini adalah untuk mengetahui pengaruh komponen Good Corporate Governance yang meliputi dewan komisaris, dewan komisaris independen, dewan direksi dan konsentrasi kepemilikan, variabel non keuangan yaitu reputasi underwriter serta variabel keuangan yaitu Return On Assets (ROA) terhadap underpricing. Pengambilan sampel memakai metode purposive sampling. Jumlah sampel akhirnya yang digunakan yaitu sebanyak 123 perusahaan dari semua sektor perusahaan yang melakukan IPO di BEI pada periode 2016-2019 dan mengalami underpricing. Data sekunder dari penelitian ini diperoleh dari prospektus, annual report, e-bursa dan IDX Factbook tahun 2016-2019. Hasil uji regresi linear berganda yaitu variabel dewan komisaris, dewan komisaris independen, dewan direksi dan Return On Assets (ROA) memiliki pengaruh dengan arah negatif terhadap underpricing yang artinya apabila jumlah anggota dewan komisaris, dewan komisaris independen, dewan direksi semakin banyak dan semakin tinggi ROA dapat meminimalisir underpricing. Sedangkan underpricing tidak dipengaruhi variabel lain yang digunakan peneliti yaitu konsentrasi kepemilikan dan reputasi underwriter.
\end{abstract}

Kata kunci: underpricing; reputasi underwriter; good corporate governance; ROA; IPO

\section{PENDAHULUAN}

Menurut Sukmawati dan Pasaribu (2017), go public merupakan upaya perusahaan menambah modal dengan menjual sahamnya ke masyarakat umum. Initial public offering (IPO) merupakan suatu proses penawaran saham penawaran saham kepada masyarakat pertama kalinya melalui pasar perdana. Menurut Lestari dan Trihastuti (2020) terdapat dua fenomena saat perusahaan melakukan IPO, yaitu underpricing dan 
overpricing. Hartono dan Nurfauziah (2019) mengatakan bahwa saat penetapan harga saham perdana dalam pasar perdana lebih rendah daripada harga penutupan di pasar sekunder dan apabila sebaliknya maka terjadilan fenomena overpricing . Dari data e-bursa dapat dilihat bahwa dari 164 perusahaan yang IPO tahun 20162019, sebanyak $92,25 \%$ dari perusahaan mengalami underpricing, $6,75 \%$ mengalami overpricing dan $1 \%$ tidak memberikan return. Hal ini menandakan bahwa fenomena underpricing banyak dialami oleh sebagian besar perusahaan yang IPO. Hartono dan Nurfauziah (2019) mengatakan bahwa underpricing ini tidak menguntungkan bagi perusahaan karena perolehan tambahan modal yang diterima tidak maksimal, sedangkan investor diuntungkan karena mendapat keuntungan berupa initial return yang didapatkan dari selisih antara harga saham pada saat penutupan di pasar sekunder dengan harga saham di pasar perdana. Menurut Lestari dan Trihastuti (2020), tingkat underpricing pasti akan diusahakan untuk diminimalisir oleh perusahaan yang go public.

Saham IPO harganya ditetapkan sesuai kesepakatan antara emiten dan underwriter. Menurut Nurazizah dan Majidah (2019), perusahaan cenderung memiliki informasi yang kurang lengkap mengenai pasar modal dibandingkan dengan underwriter, sehingga menyebabkan kemungkinan terjadinya tindakan oportunistik oleh underwriter dengan meyakinkan perusahaan bahwa harga saham perdanaya harus rendah guna mengurangi tingginya resiko yang harus ditanggung underwriter jikalau saham IPO perusahaan tidak laku. Sedangkan perusahaan tentunya mengharapkan perolehan dana yang maksimal dengan menetapkan harga saham IPO yang tinggi. Hal ini disebut sebagai konflik keagenan yang disebabkan adanya perbedaan informasi yang didapatkan kedua pihak atau asimetri informasi. Ramadana (2018) mengatakan bahwa underwriter dengan reputasi tinggi lebih percaya diri dalam menetapkan harga saham IPO guna menunujukkan kualitas penjaminannya.

Salah satu persyaratan yang ditentukan BEI bagi perusahaan yang akan melakukan IPO adalah mempunyai tata kelola perusahaan yang baik. Sinyal mengenai kualitas perusahaan dapat dilihat dari pengawasan struktur dewan, seperti ukuran dewan direksi, proporsi dewan komisaris independen dan wajarnya kepemilikan saham (Yatim, 2011 dalam Sukmawati dan Pasaribu, 2017). Dewan komisaris juga memberikan sinyal
Pengaruh Good Corporate... (Jazzlin Marvella Gunawan, Kazin Laturette)

bahwa pengelolaan perusahaan telah diawasi dengan baik yang akan meningkatkan kualitas perusahaan (Sukmawati dan Pasaribu, 2017). Dengan adanya GCG saat proses IPO, perusahaan tidak perlu menetapkan harga saham IPO yang terlalu murah, karena pasar pasti memiliki keberanian untuk membeli saham dengan harga yang tinggi asalkan perusahaan memiliki kualitas baik (Sukmawati dan Pasaribu, 2017). Konflik keagenan bisa ditimbulkan karena adanya investor pengendali dan investor minoritas dalam perusahaan dengan struktur kepemilikan terkonsentrasi dimana pemegang saham mayoritas memiliki kontrol untuk membuat keputusan untuk kepentingan pribadi. Saat membuat keputusan investasi, investor membutuhkan informasi keuangan seperti profitabilitas yang diwakilkan dengan ROA. ROA adalah suatu ukuran profitabilitas yang menginformasikan efektivitas kegiatan perusahaan dengan memanfaatkan asetnya untuk menghasilkan laba. ROA yang tinggi juga memberikan sinyal bahwa kinerja keuangan perusahaan dalam kondisi baik dan dapat meyakinkan investor bahwa return saham yang didapatkan investor di masa depan akan besar (Nurazizah dan Majidah, 2019).

Fenomena underpricing di Indonesia sudah sering diteliti, namun hasil penelitian mengenai hubungannya berbeda-beda, sehingga peneliti ingin melakukan penelitian tersendiri untuk memastikan adanya pengaruh anatara variabel corporate governance yang meliputi dewan komisaris, dewan komisaris independen, dewan direksi dan konsentrasi kepemilikan terhadap underpricing dengan menambahkan variabel keuangan yaitu ROA dan variabel non keuangan yaitu reputasi underwriter. Penulis memilih semua sektor perusahaan karena fenomena underpricing terjadi di semua sektor perusahaan dan penulis memilih periode 2016-2019 karena merupakan tahun terbaru dan pada tahun-tahun ini masih banyak perusahaan yang mengalami fenomena underpricing.

\section{LANDASAN TEORI DAN HIPOTESIS Kajian Teori}

\section{- Teori Agensi}

Konflik agensi tipe I terjadi saat adanya ketidakselarasan informasi yang diperoleh oleh manajemen dan investor (Jensen dan Meckling, 1993). Ketidakselarasan informasi ini dikarenakan investor tidak bisa memantau aktivitas-aktivitas manajer dan informasi yang diperoleh manajer investor lebih sedikit dibandingkan manajer, 
sehingga dapat menyebabkan adanya konflik dimana tindakan agen tidak mengedepankan kepentingan investor. Konflik agensi tipe II yang terjadi saat pemegang saham memiliki kontrol yang besar dalam perusahaan sehingga mereka dapat membuat keputusan sesuai kepentingan pribadi (Shelifer dan Vishny, 1997). (Kuncoro dan Suryaputri, 2019). Menurut teori agency hypothesis, underwriter sengaja menetapkah harga saham IPO menjadi underpricing untuk mengurangi risiko saham tidak laku terjual (Kuncoro dan Suryaputri, 2019).

\section{- $\quad$ Teori Signaling}

Informasi privat mengenai perusahaan bisa menjadi sinyal bagi investor dalam menentukan keputusan investasinya. Informasi yang dikeluarkan perusahaan berupa informasi keuangan dan non keuangan di masa lalu, masa sekarang dan masa yang akan datang sehingga calon investor dapat menganalisis apakah informasi perusahaan tersebut merupakan sinyal positif atau negatif dan dengan demikian calon investor bisa menilai prospek perusahaan (Adityawarman, 2017). Kualitas perusahaan yang baik dapat mengurangi ketidakpastian dan bisa menjadi sinyal positif bagi investor sehingga investor mengetahui nilai perusahaan yang sebenarnya dimana hal ini dapat mengurangi tingkat underpricing (Rustami dan Yuyetta, 2017).

\section{- Corporate governance}

FCGI (2002) menyatakan bahwa corporate governance dapat digunakan untuk mengatur hubungan stakeholder di dalam dan diluar perusahaan yang meliputi hak dan kewajibannya sehingga dapat menciptakan nilai tambah bagi stakeholder. Singkatnya corporate governance bisa dianggap sebagai sistem yang dapat mengendalikan perusahaan. Konflik keagenan antara manajemen dan pemegang saham dapat dihindari dengan adanya corporate governance. Dengan mempraktikkan GCG, investor dapat mengetahui kinerja dan kualitas suatu perusahaan (Sukmawati dan Pasaribu, 2017).

\section{- Dewan Komisaris}

KNKG (2006) menjelaskan dewan komisaris bertanggung jawab dalam mengawasi dan memberikan nasihat bagi dewan direksi, dan juga melakukan pengecekan mengenai pengelolaan perusahaan apakah telah menerapkan Good Corporate Governance.

\section{- Dewan Komisaris Independen}

Menurut BEJ (2000), komisaris independen merupakan bagian dari dewa komisaris, namun merupakan pihak eksternal dan bagi perusahaan yang mendaftarkan diri di Bursa wajib memiliki proporsi dewan komisaris independen sebesar $30 \%$ dari keseluruhan anggota dewan komisaris.

\section{- Dewan Direksi}

Menurut KNKG (2006) pihak internal perusahaan yang memiliki tugas dalam pelaksanaan aktivitas operasional perusahaan disebut sebagai dewan direksi. Pengendalian sumber daya perusahaan dan mengambil keputusan bagi perusahaan guna mencapai tujuan perusahaan ini juga merupakan tugas dan tanggung jawab dewan direksi.

\section{- Konsentrasi Kepemilikan}

Kepemilikan yang terkonsentrasi biasanya didominasi oleh investor dengan kepemilikan minimal 20\% dari total saham beredar (Fardila dan Rahmawati, 2019). Struktur kepemilikan menyebabkan prinsip keadilan lebih susah diterapkan karena investor mayoritas mempunyai kekuasaan yang lebih besar dalam memanfaatkan sumber daya perusahaan sehingga menurunkan nilai perusahaan (Njatrijani dkk., 2019).

\section{- $\quad$ Reputasi Underwriter}

Reputasi underwriter dipakai sebagai sinyal dalam meminimalisir ketidakpastian dan juga sebagai sinyal mengenai prospek perusahaan bahwa informasi perusahaan yang tertera di dalam prospektus tidak menyesatkan (Yolana dan Martani, 2005 dalam Manurung dan Nuzula, 2019).

\section{- ROA (Return on Assets)}

Menurut Lestari dan Sulasmiyati (2017), rasio yang digunakan untuk mengukur kemampuan perusahaan dalam menghasilkan laba dengan memanfaatkan total aktiva perusahaan disebut sebagai ROA.

\section{- Initial public offering (IPO)}

Istilah dalam menjualkan saham pertama kalinya ke masyarakat dikenal dengan sebutan initial public offering (IPO). Pasar perdana adalah tempat untuk menjualkan surat berharga yang diterbitkan emiten kepada masyarakat sebleum surat berharga tersebut diperjualbelikan di bursa 
efek (Hendrasih, 2017). Kesepakatan antara emiten dan underwriter yang menentukan harga saham IPO, sedangkan supply and demand menentukan harga saham di pasar sekunder (Lestari dan Trihastuti, 2020).

\section{- Underpricing}

Selisih positif dari harga saham yang dijual di bursa efek dengan harga saham yang dijual di pasar perdana atau besaran initial return merupakan suatu ukuran mengenai tingkat underpricing (Sukmawati dan Pasaribu, 2017).

\section{Pengembangan Hipotesis \\ Dewan Komisaris}

Menurut Sukmawati dan Pasaribu (2017), dengan adanya dewan komisaris memberikan sinyal positif bagi calon investor, bahwa perusahaan tersebut dikelola dengan pengawasan yang baik sehingga akan meningkatkan kualitas perusahaan dan perusahaan tidak perlu menetapkan harga yang murah bagi sahamnya (underpricing). Hasil penelitian dari Sukmawati dan Pasaribu [29], Patahita dan Yuyetta (2019), dan Hermawan dan Handayani (2018) menunjukkan hubungan signifikan negatif antara dewan komisaris dengan tingkat underpricing. Dari penjelasan diatas dapat dikembangkan hipotesis pertama, yaitu:

$\mathrm{H}_{1}$ : Ukuran dewan komisaris memiliki pengaruh negatif terhadap underpricing saat IPO periode 2016-2019.

\section{- Dewan Komisaris Independen}

Adanya monitoring dari dewan komisaris independen sebagai pihak eksternal yang tidak memiliki afiliasi dengan perusahaan, mampu mengeluarkan sinyal bagi investor bahwa praktik corporate governance sudah dilaksanakan sehingga kuaitas manajemen meningka. Hal ini menyebabkan pada saat IPO penetapan harga sahamnya bisa diterima investor lebih tinggi karena perusahaan berkualitas baik, sehingga dapat meminimalisir tingkat underpricing. Menurut Hermawan dan Handayani (2018) dewan komisaris independen memiliki hubungan signifikan negatif dengan underpricing. Dari penjelasan tersebut, dapat dikembangkan hipotesis kedua yaitu:

$\mathrm{H}_{2}$ : Jumlah dewan komisaris independen memiliki pengaruh negatif terhadap underpricing saat IPO periode 2016-2019.

\section{- Dewan Direksi}

Investor memiliki asumsi bahwa semakin banyak dewan direksi maka tujuan perusahaan lebih mudah tercapai. Hasil dari penelitian Purwanto (2019) menyatakan hubungan signifikan negatif antara dewan direksi dengan underpricing yang memiliki arti semakin banyak anggota dewan direksi, maka semakin menurun tingkat underpricing. Oleh karena itu, dapat dikembangkan hipotesis ketiga:

$\mathrm{H}_{3}$ : Ukuran dewan direksi memiliki pengaruh negatif terhadap underpricing saat IPO periode 2016-2019.

\section{- Konsentrasi Kepemilikan}

Apabila perusahaan menetapkan harga saham IPO underpricing, investor mayoritas akan menambah kepemilikan sahamnya agar bisa mempertahankan kontrol efektif atas perusahaan tersebut. Maurya dan Singh (2018), menemukan hubungan signifikan positif antara konsentrasi kepemilikan dan underpricing. Sedangkan Nurazizah dan Majidah (2019) tidak menemukan pengaruh antara konsentrasi kepemilikan dengan underpricing. Dari penjelasan tersebut, dapat dikembangkan hipotesis keempat yaitu:

$\mathrm{H}_{4}$ : Konsentrasi kepemilikan memiliki pengaruh positif terhadap underpricing saat IPO periode 2016-2019.

\section{- $\quad$ Reputasi Underwriter}

Menurut teori keagenan, untuk meminimalisir risiko saham tidak laku terjual underwiter sengaja membuat harga saham IPO murah dan menyebabkan underpricing. Underwriter yang memiliki reputasi rendah dapat melakukan hal ini untuk menghindari risiko. Menurut penelitian dari Akbar dan Africano (2019), Kuncoro dan Suryaputri (2019), Adityawarman (2017), serta Manurung dan Nuzula (2019) menemukan hasil yang sama yaitu reputasi underwriter memiliki pengaruh signifikan negatif dengan underpricing. Sedangkan Gardika dan Isbanah (2020) tidak menemukan pengaruh antara reputasi underwriter dan underpricing. Dengan penjelasan tersebut, dapat dikembangkan hipotesis kelima:

$\mathrm{H}_{5}$ : Reputasi underwriter memiliki pengaruh negatif terhadap underpricing saat IPO periode 2016-2019.

\section{- $\quad$ Return on Assets (ROA)}

Tingginya ROA dapat meminimalisir 
ketidakpastian mengenai prospek perusahaan sehingga akan mengurangi tingkat underpricing. Menurut penelitian Lestari dan Sulasmiyati (2020), Marlina dkk. (2017), Gardika dan Isbanah (2020) menemukan hasil yang sama yaitu ROA memiliki pengaruh signifikan dan negatif terhadap underpricing. Oleh karena itu dapat dikembangkan hipotesis keenam :

$H_{6}$ : ROA memiliki pengaruh negatif terhadap underpricing saat IPO periode 2016-2019.

\section{METODE PENELITIAN}

\section{- Jenis Penelitian}

Penelitian ini merupakan penelitian kuantitaif berjenis explanatory research yang berguna untuk menjelaskan kedudukan variabel-variabel yang diteliti serta hubungan antara variabel yang satu dengan yang lain (Kurnia, 2018). Dimensi waktu yang digunakan dalam penelitian yaitu cross sectional study, yang merupakan penelitian yang mengumpulkan data-data hanya sekali dalam satu periode untuk menjawab suatu pertanyaan penelitian (Purwanto, 2019). Peneliti hanya mengambil data satu kali dalam penelitian ini yaitu periode waktu 1 Januari 2016 - 31 Desember 2019.

\section{- Populasi dan Sampel}

Populasi yang digunakan yaitu semua sektor perusahaan yang melakukan IPO dan tercatat di Bursa Efek Indonesia (BEI) selama periode tahun amatan yaitu 2016-2019 dengan total 164 perusahaan. Teknik pengambilan sampel yang dipakai peneliti adalah purposive sampling, dimana teknik penentuan sampel dikumpulkan berdasarkan target yang telah dipertimbangkan oleh peneliti sesuai dengan tujuan penelitian (Rustami dan Yuyetta, 2017). Sampel perusahaan yang dipakai dalam penelitian adalah yang memenuhi kriteria peneliti yaitu perusahaan yang melakukan IPO di BEI periode 2016-2019 dan sahamnya mengalami underpricing, tersedia propspektus, laporan keuangan dan bukan merupakan data outlier. Berdasarkan kriteria yang ditentukan, jumlah sampel yang didapatkan adalah 123 perusahaan dari semua sektor yang melakukan IPO periode 2016-2019.

\section{Definisi Operasional dan Pengukuran Variabel Underpricing}

Pengukurannya yaitu berdasarkan initial return yang merupakan selisih positif antara harga saham di pasar sekunder pada saat penutupan dengan harga saham sewaktu pertama kali ditawarkan di pasar perdana dibagi dengan harga saham di pasar perdana dan dikalikan dengan 100\% (Hermawan dan Handayani, 2018)

$\mathrm{IR}=\frac{\frac{P 1-P 0}{p 0}}{P 0} \times 100 \% \frac{p 1-P 0}{P 0} X 100 \%$

$\mathrm{IR}=$ Initial Return

$\mathrm{P} 0=$ Harga saham di pasar perdana

$\mathrm{P} 1$ = Harga saham penutupan hari pertama di pasar sekunder

\section{Dewan Komisaris}

Pengukurannya yaitu dengan dengan melihat total keseluruhan jumlah dewan komisaris yang bekerja di perusahaan saat IPO (Hermawan dan Handayani, 2018).

\section{Dewan Komisaris Independen}

Pengukurannya melalui persentase antara jumlah keseluruhan komisaris independen dengan total keseluruhan anggota dewan komisaris perusahaan (Hermawan dan Handayani, 2018).

Dewan Komisaris Independen $=$

Tumlah komisaris independen

Total keseluruhan dewan komisaris $\mathrm{x} 100 \%$

Tumlah komisaris independen

Total keseluruhan dewan komisaris

\section{Dewan Direksi}

Pengukurannya yaitu dengan menjumlahkan seluruh anggota dewan direksi yang menjabat dalam perusahaan pada saat IPO (Purwanto, 2019).

\section{Konsentrasi Kepemilikan}

Pengukurannya yaitu dengan melihat persentase pemegang saham terbesar (Nurazizah dan Majidah, 2019)

\section{Reputasi Underwriter}

Variabel reputasi underwriter diukur dari peringkat di BEI mengenai "The Most Active IDX Members in Total Trading Volume" yang terdapat dalam IDX Fact Book (Adityawarman, 2017).

\section{Return On Assets (ROA)}

Pengurukurannya dengan melihat persentase laba bersih setelah pajak dan total asset

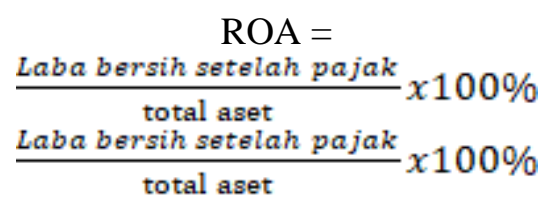


p-ISSN 1693-1378

e-ISSN 2598-9952

\section{Metode Pengumulan Data}

Metode dalam mengumpulkan data memakai metode dokumentasi dilakukan penelusuran terhadap data sekunder yang berupa prospektus perusahaan IPO periode 2016-2019. Data ini didapatkan melalui website IDX terbitan BEI. Untuk underwriter dari emiten diperoleh dari prospektus dan top 10 ditentukan berdasarkan "The Most Active IDX Members in Total Trading Volume" yang terdapat dalam IDX Fact Book. Selain itu, peneliti juga menelusuri berbagai referensi lainnya seperti jurnal-jurnal yang berkaitan dan data pendukung berupa annual report perusahaan.

\section{- Metode Analisis Data}

Pengujian hipotesis memakai analisis regresi berganda, yang harus memenuhi persyaratan uji asumsi klasik yang meliputi uji normalitas, uji heteroskedasitas dan uji multikolinearitas. Penelitian ini tidak memerlukan uji autokorelasi karena merupakan data cross section (Ansofino dkk, 2016). Uji hipotesis terdiri dari uji $\mathrm{F}$, uji $\mathrm{t}$ dan uji koefisien determinasi $\left(\mathrm{R}^{2}\right)$. Uji-uji tersebut dilakukan dengan menggunakan SPSS 25. Persamaan regresi linear berganda diformulasikan sebagai berikut:

\section{$\mathrm{Y}=\alpha+\beta 1 \mathrm{X} 1+\beta 2 \mathrm{X} 2+\beta 3 \mathrm{X} 3+\beta 4 \mathrm{X} 4+\beta 5 \mathrm{X} 5+$ $\beta 6 \times 6+\varepsilon$ \\ Keterangan:}
Y : Underpricing
A : Konstanta
$\mathrm{X}_{1}$ : Dewan Komisaris
$\mathrm{X}_{2}$ : Dewan Direksi
$\mathrm{X}_{3}$ : Dewan Komisaris Independen
$\mathrm{X}_{4}$ : Konsentrasi Kepemilikan
$\mathrm{X}_{5}$ : Reputasi Underwriter
$\mathrm{X}_{6}:$ Return on Assets (ROA)
$\varepsilon$ : error term

\section{PEMBAHASAN}

Berdasarkan penjelasan yang dilampirkan diatas, peneliti melakukan analisis data menggunakan aplikasi SPPS 25.

Uji Asumsi Klasik

Uji Normalitas

Tabel 1

Hasil Uji Normalitas

\begin{tabular}{|l|l|}
\hline $\mathbf{N}$ & 123 \\
Test Statistic & 0,078 \\
\hline Asymp. Sig. (2-tailed) & 0,062 \\
\hline
\end{tabular}

Sumber : Data olahan SPSS 25, 2020
Pengaruh Good Corporate... (Jazzlin Marvella Gunawan, Kazin Laturette)

Hasil Tabel 1 memperlihatkan nilai uji normalitas dengan Kolmogorov-Smirnov sebesar 0,062. Data yang digunakan dinyatakan berdistribusi normal karena nilai Asymp.Sig.(2tailed) sebesar 0,062 dimana lebih dari 0,05.

Uji Multikolinearitas

Tabel 2

Hasil Uji Multikolinearitas

\begin{tabular}{|l|c|c|}
\multicolumn{1}{|c|}{$\begin{array}{c}\text { Coefficients } \\
\text { Model }\end{array}$} & Tolerance & VIF \\
\hline Dewan Komisaris & 0,757 & 1,321 \\
\hline $\begin{array}{l}\text { Dewan Komisaris } \\
\text { Independen }\end{array}$ & 0,857 & 1,167 \\
\hline Dewan Direksi & 0,790 & 1,266 \\
\hline $\begin{array}{l}\text { Konsentrasi } \\
\text { Kepemilikan }\end{array}$ & 0,938 & 1,066 \\
\hline Reputasi Underwriter & 0,826 & 1,211 \\
\hline ROA & 0,960 & 1,042 \\
\hline
\end{tabular}

Sumber : Data olahan SPSS 25, 2020

Tabel 2 memperlihatkan nilai tolerance keenam variabel independen penelitian lebih dari 0,10 dalam artian lain memiliki nilai VIF lebih kecil daripada 10, artinya tidak ada korelasi antar variabel independen dan merupakan model regresi yang baik.

Uji Heteroskedasitas

Tabel 3

\begin{tabular}{ll} 
Hasil Uji Heteroskedasitas (Uji Park) \\
\hline Coefficients & Sig. \\
\hline Model & 0,362 \\
\hline Dewan Komisaris & 0,578 \\
\hline Dewan Komisaris Independen & 0,178 \\
\hline Dewan Direksi & 0,423 \\
\hline Konsentrasi Kepemilikan & 0,237 \\
\hline Reputasi Underwriter & 0,277 \\
\hline ROA &
\end{tabular}

Sumber : Data olahan SPSS 25, 2020

Tabel 3 memperlihatkan nilai signifikansi variabel independen keseluruhan adalah lebih dari 0,05 yang berati tidak terjadinya heteroskedasitas.

\section{Hasil Uji Regresi Linear Berganda}

Berdasarkan hasi uji regresi yang dilampirkan pada Tabel 5 persamaan regresi linear berganda diformulasikan sebagai berikut :

$\mathrm{Y}=1,137-0,08 \mathrm{X}_{1}-0,369 \mathrm{X}_{2}-0,037 \mathrm{X}_{3}-0,038 \mathrm{X}_{4}$ $-0,063 \mathrm{X}_{5}-0,507 \mathrm{X}_{6}$ 
Koefisien dari dewan komisaris -0,08, koefisien dari dewan komisaris independen 0,369 , koefisien dewan direksi $-0,037$, koefisien konsentrasi kepemilikan -0,038, koefisien reputasi underwriter -0,063 dan koefisien ROA -0,507. Koefisien enam variabel independen yang digunakan menunjukkan arah hubungan yang negatif atau dengan kata lain jika nilai variabel independen meningkat, maka tingkat underpricing akan menurun.

\section{Uji Hipotesis}

Uji F

Tabel 4
Hasil Uji F
\begin{tabular}{|l|l|}
\hline ANOVA \\
Model & Sig. \\
\hline 1 & $0,000^{\mathrm{b}}$ \\
\hline
\end{tabular}

Sumber: Data olahan SPSS 25, 2020

Tabel 4 memperlihatkan bahwa variabel independen secara bersama-sama mempengaruhi variabel dependen karena tingkat signifikansinya $0,00<0,05$.

Uji t

Tabel 5

Uji t

\begin{tabular}{lcc}
\hline Coefficients & & \\
\hline Model & B & Sig. \\
Konstanta & 1,137 & 0,000 \\
\hline Dewan Komisaris & $-0,080$ & 0,000 \\
\hline $\begin{array}{l}\text { Dewan Komisaris } \\
\text { Independen }\end{array}$ & $-0,369$ & 0,044 \\
\hline Dewan Direksi & $-0,037$ & 0,006 \\
\hline Konsentrasi Kepemilikan & $-0,038$ & 0,565 \\
\hline Reputasi Underwriter & $-0,063$ & 0,064 \\
\hline ROA & $-0,507$ & 0,004 \\
\hline
\end{tabular}

Sumber : Data olahan SPSS 25, 2020

Tabel 5 yang menunjukkan hasil dari uji $\mathrm{t}$ menjelaskan adanya pengaruh negatif antara dewan komisaris dan underpricing dikarenakan arah koefisien beta yang dihasilkan sebesar $-0,8$ dan memiliki arah negatif, selain itu besar nilai signifikansi adalah 0,00 dimana kurang dari 0,05 yang berarti $\mathbf{H}_{\mathbf{1}}$ diterima. Arah negatif menjelaskan dewan komisaris apabila semakin banyak dapat meminimalisir underpricing dikarenakan adanya peningkatan dalam efektivitas pengawasan terhadap dewan direksi dan menjadi sinyal untuk investor mengenai pengelolan perusahaan yang sudah baik yang akan meningkatkan kualitas perusahaan sehingga tidak diperlukan menetapkan harga saham IPO terlalu murah (Sukmawati dan Pasaribu, 2017). Penelitian ini hasilnya sesuai dengan penelitian dari Sukmawati dan Pasaribu (2017), Patahita dan Yuyetta (2019) dan Hermawan dan Handayani (2018) bahwa dewan komisaris memiliki pengaruh negatif terhadap underpricing.

Hasil uji t menjelaskan adanya pengaruh negatif antara dewan komisaris independen dan underpricing dikarenakan arah koefisien beta yang dihasilkan sebesar -0,369 dan memiliki arah negatif, selain itu besar nilai signifikansi adalah 0,044 dimana nilai ini kurang dari 0,05 berarti bahwa $\mathbf{H}_{2}$ diterima. Arah negatif menjelaskan bahwa anggota dari dewan komisaris independen yang semakin besar akan menurunkan underpricing, karena merupakan pihak luar yang netral dan tidak mempunyai hubungan dengan perusahaan sehingga tindakannya tidak dapat dipengaruhi. Komisaris independen juga akan menjalankan pengawasan dalam pengambilan keputusan guna mencegah adanya tindakan oportunistik dari manajemen (Patahita dan Yuyetta, 2019). Monitoring dari dewan komisaris independen sebagai pihak eksternal akan memberikan sinyal bagi investor bahwa praktik corporate governance sudah dilakukan, sehingga dapat menjadi sinyal mengenai peningkatan kualitas perusahaan dan perusahaan tidak perlu menetapkan harga yang terlalu murah bagi sahamnya yang akan mengurangi tingkat underpricing. Penelitian ini hasilnya sesuai dengan penelitian dari Hermawan dan Handayani (2018), bahwa dewan komisaris independen memiliki pengaruh negatif terhadap underpricing.

Hasil uji t menjelaskan adanya pengaruh negatif antara dewan direksi dan underpricing dikarenakan arah koefisien beta yang dihasilkan sebesar -0,037 dan memiliki arah negatif, selain itu besar nilai signifikansi adalah 0,006 dimana kurang dari 0,05 yang berarti $\mathbf{H}_{3}$ diterima. Arti dari arah yang negatif adalah jika anggota dewan direksi semakin banyak akan semakin baik karena dapat mengurangi tingkat underpricing. Dewan direksi sebagai pihak internal perusahaan yang bertugas dalam pelaksanaan aktivitas operasional perusahaan dan mengambil keputusan bagi perusahaan. Apabila pembagian tugas sudah jelas dan memiliki fungsi yang lengkap sehingga menjadi sinyal untuk investor bahwa perusahaan berkualitas baik, dan semakin banyak dewan direksi akan menjadi sinyal bahwa tujual perusahaan lebih mudah tercapai (Purwanto, 2018). Perusahaan yang memiliki kualitas baik 
tidak perlu mentapkan harga yang terlalu murah untuk saham IPOnya sehingga dapat meminimalisir underpricing. Saham yang berkualitas baik pasti akan diminati investor meskipun harganya lebih tinggi (Sukmawati dan Pasaribu, 2017). Penelitian ini hasilnya sesuai penelitian dari Purwanto (2019) bahwa dewan direksi berpengaruh negatif terhadap underpricing.

Hasil uji t menjelaskan bahwa antara konsentrasi kepemilikan dan underpricing tidak mempunyai pengaruh, dikarenakan besar signifikansinya 0,565 dimana nilai ini melebihi 0,05 yang berati $\mathbf{H}_{\mathbf{4}}$ ditolak. Hasil ini menjelaskan bahwa konsentrasi kepemilikan baik tinggi/ rendah tidak memberikan pengaruh terhadap underpricing, karena persentase kepemilikan saham oleh pemegang saham mayoritas sebelum IPO cenderung sama dengan sebelum tercatat di BEI. Perubahan kepemilikan menjadi saham publik yaitu pada saat saham tercatat di BEI (pasar sekunder) sehingga konsentrasi kepemilikan tidak dapat menjadi jaminan untuk meminimalisir underpricing (Nurazizah dan Majidah, 2019). Penelitian ini hasilnya sesuai dengan penelitian dari Maurya dan Singh (2018) yang menemukan hubungan signifikan positif antara konsentrasi kepemilikan dan underpricing. Hasil penelitian ini sejalan dengan penelitian sebelumnya yang dilakukan oleh Nurazizah dan Majidah (2019) bahwa konsentrasi kepemilikan tidak mempengaruhi underpricing.

Hasil uji $t$ menjelaskan tidak adanya pengaruh antara reputasi underwriter dan underpricing dikarenakan besar signifikansi 0,064 melebihi 0,05 yang berati $\mathbf{H}_{5}$ ditolak. Hasil ini menjelaskan bahwa semakin tinggi/ rendah reputasi underwriter tidak memiliki pengaruh terhadap underpricing, tetapi dipengaruhi oleh kesepakatan harga antara perusahaan dan underwriter (Gardika dan Isbanah, 2020). Investor tidak terlalu mempertimbangkan reputasi underwriter dalam berinvestasi, karena menurut investor perusahaan akan memilih underwriter dengan reputasi baik demi kesuksesan proses IPOnya. Penelitian ini hasilnya tidak sejalan dengan penelitian dari Akbar dan Africano (2019), Kuncoro dan Suryaputri (2019), Adityawarman (2017), serta Manurung dan Nuzula (2019) yang menemukan hasil bahwa reputasi underwriter memiliki pengaruh signifikan negatif terhadap underpricing. Namun, sejalan dengan penelitian dari Gardika dan Isbanah (2020) bahwa reputasi underwriter dan
Pengaruh Good Corporate... (Jazzlin Marvella Gunawan, Kazin Laturette)

underpricing tidak memiliki pengaruh.

Hasil uji t menjelaskan adanya pengaruh negatif antara dewan ROA dan underpricing dikarenakan arah koefisien beta yang dihasilkan sebesar -0,507 dan memiliki arah negatif, besaran signifikansinya 0,004 dimana nilai ini kurang dari 0,05 yang berati $\mathbf{H}_{6}$ diterima. Arah negatif ini menjelaskan bahwa nilai ROA yang besar bisa menurunkan underpricing, dikarenakan profitabilitas yang semakin tinggi dapat meminimalisir ketidakpastian di pandangan calon investor yang juga akan meminimalisir tingkat underpricing (Permatasari dan Kusumah, 2017). ROA yang semakin tinggi bisa mengurangi ketidakpastian perusahaan di masa depan dan mengurangi ketidakpastian IPO (Marlina dkk., 2017). Tingginya nilai ROA akan meningkatkan minat calon investor terhadap saham IPO perusahaan sehingga tidak diperlukan bagi perusahaan untuk menetapkan harga yang terlalu rendah bagi saham IPOnya (Nurazizah dan Majidah, 2019). Penelitian ini mempunyai hasil yang sesuai dengan peneletian dari Lestari dan Sulasmiyati (2017), Marlina dkk. (2017), Gardika dan Isbanah (2020) menemukan hasil yang sama yaitu ROA berpengaruh signifikan dan negatif terhadap underpricing.

Uji Koefisien Determinasi $\left(R^{2}\right)$

Tabel 6
Hasil Uji Koefisien Determinasi $\left(\mathbf{R}^{\mathbf{2}}\right)$
\begin{tabular}{|c|c|}
\hline Model Summary \\
\hline Model & Sadjusted R Square. \\
\hline 1 & $0,000^{\mathrm{b}}$ \\
\hline Sumber : Data olahan SPSS 25,2020
\end{tabular}

Berdasarkan Tabel 6, bisa diketahui nilai Adjusted $R$ Squarenya sebesar 0,374 atau 37,4\%. Hal ini berati bahwa underpricing dapat dijelaskan oleh variabel independen yang digunakan peneliti sebesar $37,4 \%$ dan sisanya yaitu $62,6 \%$ dapat dijelaskan oleh sebab-sebab lainnya diluar variabel yang diteliti.

\section{PENUTUP}

\section{Kesimpulan}

Berdasarkan uji hipotesis yang dilakukan, hasil dari penelitian menggunakan data yang diambil dari Bursa Efek Indonesia periode 20162019 yaitu dewan komisaris, dewan komisaris independen, dewan direksi dan ROA berpengaruh signifikan negatif terhadap underpricing saat IPO, sedangkan konsentrasi kepemilikan dan reputasi underwriter tidak berpengaruh terhadap 
underpricing saat IPO.

\section{Keterbatasan dan Saran}

Penelitian ini mempunyai keterbatasan berupa penggunaan variabel keuangan sebatas ROA saja, sehingga kurang menjelaskan faktorfaktor keuangan lainnya yang menyebabkan underpricing. Sampel perusahaan yang digunakan tidak mencakup tahun 2020, karena belum berakhirnya tahun tersebut sehingga tidak dapat diteliti. Padahal hingga September 2020 jumlah perusahaan yang melakukan IPO cukup banyak yaitu 46 perusahaan. Menariknya adalah meskipun di tahun ini terjadi pandemi Covid-19, namun perusahaan tetap tertarik untuk melakukan IPO.

Saran yang ingin disampaikan peniliti untuk perusahaan yaitu, diharapkan perusahaan bisa melaksanakan praktik corporate governance dengan baik supaya bisa menjadi sinyal positif bagi calon investor. Perlu juga bagi perusahaan untuk mempertahankan bahkan meningkatkan angka ROA guna meyakinkan investor bahwa aset perusahaan dikelola secara efektif untuk menghasilkan laba maksimal. Perusahaan berkualitas baik diharapkan tidak menetapkan harga saham IPO terlalu murah, karena investor pasti memiliki keberanian yang lebih untuk membeli saham berkualitas dengan harga tinggi sehingga dapat meminimalisir underpricing. Untuk investor diharapkan dapat memilih untuk membeli saham bukan karena harga yang murah, tetapi terlebih dahulu melihat kualitas perusahaan agar dapat memberikan return yang baik kedepannya. Untuk penelitian selanjutnya disarankan untuk melihat reputasi underwriter melalui trading value sebagaimana penelitian yang dilakukan oleh Kuncoro dan Suryaputri (2019). Selain itu perlu menambahkan sampel tahun 2020, karena minat IPO 2020 masih sangat baik meskipun adanya pandemic Covid-19 dan perlu menambahkan variabel ROE untuk mewakili rasio profitabilitas yang lainnya serta variabel reputasi auditor dengan menggunakan auditor dari KAP guna meminimalisir ketidakpastian dan memberikan sinyal bahwa informasi yang diberikan memang sebenarbenarnya (Adityawarman, 2017).

\section{DAFTAR PUSTAKA}

Adityawarman, E. K. A. (2017). Pengaruh Reputasi Auditor, Reputasi Underwriter, Dan Persentase Free Float Terhadap Tingkat Underpricing Pada Initial Public
Offering. Diponegoro Journal of Accounting Volume 6, Nomor 2, Pp. 2-7.

Akbar, D. A. \& Africano, F. (2019). Pengaruh Reputasi Underwriter Dan Umur Perusahaan, Terhadap Underpricing Saham Pada Saat Initial Public Offering. Jurnal Al Qardh, Volume 4, Pp. 130-138.

Ansofino, Jolianis, Yolamalinda, \& Arfilindo, $\mathrm{H}$. (2016). Buku Ajar Ekonometrika. Yogyakarta: Dipublish.

BEJ. (2000). Peraturan Pencatatan Efek Nomor IA : Tentang Ketentuan Umum Pencatatan Efek Bersifat Ekuitas Di Bursa. [Online].

e-bursa. (2016). E-Bursa. [Online] Available At: Https://Www.E-

Bursa.Com/Index.Php/Ipo/Ipo_Stock_Perfo rmance

Fardila, R. \& Rahmawati, S. (2019). Pengaruh Konsentrasi Kepemilikan Dan Asimetriinformasi Terhadap Underpricing Saham Pada Saatinitial public offering (Ipo) Di Bursa Efek Indonesia. Jurnal Ilmiah Mahasiswa Ekonomi Manajemen Vol. 4, No. 3, Pp. 434-443.

FCGI. (2002). Peranan Dewan Komisaris Dan Komite Audit Dalam Pelaksanaan Corporate governance. [Online].

Gardika, D. \& Isbanah, Y. (2020). Pengaruh Corporate governance, Variabel Keuangan, Dan Non Keuangan Terhadap Underpricing Pada Perusahaan Yang IPO Tahun 20142017. Jurnal Ilmu Manajemen Volume 8 Nomor 1, Pp. 182-194.

Hartono, T. D. \& Nurfauziah. (2019). Pengaruh Reputasi Underwriter, Reputasi Auditor, Dan Return on Asset Terhadap Fenomena Underpricing Pada Initial Public Offering Di Bursa Efek Indonesia. Business Management Journal Vol.15 (No.2), P. 110.

Hendrasih, I. (2017). Strategi Membeli Initial Public Offering (IPO) Di Pasar Modal Perdana Indonesia. Jurnal Moneter Vol. IV No. 2, Pp. 166-168.

Hermawan, F. D. \& Handayani, R. S. (2018). Pengaruh Struktur Kepemilikan Dan Struktur Dewan Terhadap Tingkat Underpricing. Diponegoro Journal of Accounting Volume 7, Nomor 4, Pp. 1-11.

KNKG. (2006). Pedoman Umum Good Corporate Governance Indonesia. [Online].

Kuncoro, H. B. \& Suryaputri, R. V. (2019). Analisis Faktor-Faktor Yang Mempengaruhi Underpricing Saham Pada Penawaran Umum Perdana. Jurnal 
p-ISSN 1693-1378

e-ISSN 2598-9952

Akuntansi Trisakti Volume. 6 Nomor. 2, Pp. 263-282.

Kurnia, T. (2018). Bisnis. [Online]

Available

At:

Https://Www.Liputan6.Com/Bisnis/Read/3

688332/Penduduk-265-Juta-Orang-Hanya-

13-Juta-Warga-Ri-Yang-Bayar-Pajak

Lestari, F. A. \& Sulasmiyati, S. (2017). Pengaruh Informasi Keuangan Terhadap Underpricing (Studi Pada Perusahaan Yang Melaksanakan IPO Pada Bursa Efek Indonesia Tahun 2012). Jurnal Administrasi Bisnis (JAB) Vol. 46 No. 2, Pp. 2-6.

Lestari, Y. S. \& Trihastuti, A. (2020). Pengaruh Ukuran Perusahaan, Reputasi Underwriter, Return on asset (Roa), Return On Equity (Roe) Dan Financial Leverage Terhadap Underpricing Saham Initial Public Offering (IPO) Pada Pasar Perdana Di Bursa Efek Indonesia Periode 2012-2016. Jurnal Ekonomi Akutansi Volume 5. Nomer 1., Pp. 39-43.

Manurung, S. T. A. \& Nuzula, N. F. (2019). Pengaruh Variabel Non Keuangan Terhadap Underpricing Pada Saat Initial Public Offering (IPO). Jurnal Administrasi Bisnis (Jab) Vol. 69 No. 1, Pp. 59-64.

Marlina, Widhianningrum, P. \& Astuti, E. (2017). Pengaruh Debt To Equity Ratio Dan Return on Asset Terhadap Underpricing Saham Perdana Pada Perusahaan-Perusahaan Yang Terdaftar Di Bursa Efek Indonesia Periode 2011-2015. The 9th FIPA: Forum Ilmiah Pendidikan Akuntansi, Pp. 440-446.

Maurya, S. \& Singh, A. K. (2018). Corporate governance, Ownership Structure And Ipo Underpricing: Evidence From Indian New Issue Market. Indian Journal of Research In Capital Markets, Pp. 2-16.

Njatrijani, R., Rahmanda, B. \& Saputra, R. D. (2019). Hubungan Hukum Dan Penerapan Prinsip Good Corporate Governance
Pengaruh Good Corporate... (Jazzlin Marvella Gunawan, Kazin Laturette)

Dalam Perusahaan. Jurnal Gema Keadilan Volume 6, Edisi Iii, Pp. 244-259.

Nurazizah, N. D. \& Majidah. (2019). Analisis Faktor-Faktor Yang Mempengaruhi Tingkat Underpricing Pada Saat Initial Public Offering (IPO) Di Bursa Efek Indonesia. Jurnal Ilmiah Mea Vol. 3 No. 3, P. 161.

Patahita, N. P. \& Yuyetta, E. N. A. (2019). Analisis Pengaruh Struktur Dewan Komisaris,Kepemilikan, Dan Variabel Reputasi Terhadap IPO Underpricing Di Indonesia. Diponegoro Journal of Accounting Volume 8, Nomor 2, Pp. 2-10.

Permatasari, R. \& Kusumah, R. W. R. (2017). Pengaruh Return on Asset, Price Earning Ratio, Ukuran Perusahaan, Prosentase Penawaran Saham, Dan Reputasi Underwriter Terhadap Tingkat Underpricing. Snab, Pp. 261-264.

Purwanto, B. N. C. (2019). Struktur Corporate governance, Reputasi Underwriter Dan Initial Public Offering (IPO) Underpricing Di Indonesia. Ekonomi Bisnis Dan Kewirausahaan, Pp. 22-27.

Ramadana, S. W. (2018). Beberapa Faktor Yang Mempengaruhi Underpricing Saham Pada Perusahaan Yang Melakukan Initial Public Offering (IPO) Di Bursa Efek Indonesia. Jurnal Riset Inspirasi Manajemen Dan Kewirausahaan Volume 2 No. 2, Pp. 103105.

Rustami, O. \& Yuyetta, E. N. A. (2017). Analisis Pengaruh Biaya Audit, Praktik Tata Kelolaperusahaan, Dan Struktur Kepemilikan Terhadap IPO Underpricing. Diponegoro Journal of Accounting Volume 6, Nomor 3, Pp. 2-12.

Sukmawati, K. \& Pasaribu, R. B. F. (2017). Pengaruh Mekanisme Good Corporate Governance Terhadap Underpricing (Studi Pada Perusahaan Yangmelakukan Initial Public Offering Di BEI Periode 20102014). UG Jurnal Vol.11 No.03, Pp. 1-10. 